\title{
34. HIGH-RESOLUTION ELECTRICAL IMAGING IN THE NEW HEBRIDES ISLAND ARC: STRUCTURAL ANALYSIS AND STRESS STUDIES
}

\author{
Thierry J. Chabernaud ${ }^{2}$
}

\begin{abstract}
Electrical images recorded with the Formation MicroScanner in three of seven holes drilled during Leg 134 were analyzed to study the effect of the collision of the d'Entrecasteaux Ridge with the central New Hebrides Island Arc. Structural features such as bedding, faults, fractures, folds, and shear zones, automatically detected and interactively mapped from the images, were interpreted to document the deformation processes caused by the collision. At Site 829 the images show the imbricated structure of the thrust sheets in the accretionary complex. At Sites 832 and 833 the structural features observed and the compressional-stress information inferred from breakout analyses and hydraulic fractures indicate that the intra-arc North Aoba Basin is still subject to a east-northeast-west-southwest compression. This compression, which is associated with the uplift of the eastern part of the basin, is not older than latest Pliocene.
\end{abstract}

\section{INTRODUCTION}

Leg 134 generated abundant structural data that include core measurements corrected to geographic coordinates provided by paleomagnetic data and information about in-situ geological planar features determined from electrical images of the borehole wall recorded with the Formation MicroScanner logging tool (FMS, mark of Schlumberger), an imaging dipmeter, and from acoustic images from the borehole televiewer (BHTV). The structures observed by FMS fall into four main categories: bedding planes, fractures, small faults, and shear zones. The determination, orientation, and interpretation of these features derived by quantitative image analysis have been used successfully to provide sedimentary, structural, and tectonic information (Pezard and Luthi, 1988; Plumb and Luthi, 1989). The four-arm calipers and the inclinometer of the FMS tool provide continuous measurements of borehole diameter and orientations in perpendicular directions. These measurements can be used to detect and characterize zones of borehole elongation.

Previous studies have shown that stress-related borehole elongations, also known as breakouts, align with the least compressive stress (Gough and Bell, 1982; Plumb and Hickman, 1985); thus, borehole elongation provides easy and efficient means for evaluating far-field tectonic stresses. The contemporary stress orientation can also be derived from the observation of vertical drilling-induced fractures that theoretically parallel the direction of the maximum horizontal stress (Rummel, 1988). Although the FMS tool, which has a borehole coverage of $25 \%$, is not as efficient as the $360^{\circ}$ acoustical borehole televiewer in monitoring both stress indicators (Krammer and Chabernaud, this volume), it has been run more frequently and has produced extremely useful data. Analyses of data and comparisons to core observations are particularly interesting for studying the deformation processes of the central New Hebrides Island Arc and the effects of its subduction-collision with the d'Entrecasteaux Ridge on the intra-arc North Aoba Basin. In this chapter I will report on and attempt to interpret the most significant structural features observed with the FMS from three out of the seven sites occupied during Leg 134 (Fig. 1). Site 829 penetrated the accretionary complex located on the arc slope where the d'Entrecasteaux Ridge collides with the island arc. Sites 832 and 833 are located in the central part and the eastern flank of the intra-arc

${ }^{1}$ Greene, H.G., Collot, J.-Y., Stokking, L.B., et al., 1994. Proc. ODP, Sci. Results, 134: College Station, TX (Ocean Drilling Program).

${ }^{2}$ Lamont-Doherty Earth Observatory, Columbia University, Palisades, NY 10964. U.S.A.
North Aoba Basin and were drilled to investigate the effect of the d'Entrecasteaux Ridge on the development of the basin.

\section{STRUCTURAL ANALYSIS}

\section{Methods}

The FMS produces an electrical resistivity image of the borehole wall that resembles a core photograph (Ekstrom et al., 1986; Serra, 1989). The FMS data help to identify and to measure the orientation of laterally continuous geological features that intersect the borehole, such as bedding planes, faults, fractures, or shear zones. Any planar structure that crosses a cylindrical borehole appears on the unwrapped, oriented image as segments of a sine wave. The features may be analyzed in three ways. Interactive image analysis on graphics workstations allows scrolling through images and mapping structural features; strike and dip are then computed using the image orientation and borehole geometric parameters. Although the process is time consuming, the FMS provides the most reliable data (Serra, 1989). Other methods have been developed to recognize planar structures and to compute their orientations. One method consists of cross-correlating eight of the 64 conductive traces recorded with the FMS to find vertical displacements around the borehole. The best-fit planes of consistent displacements are assumed to correspond to geological features and their orientation can be computed using borehole geometry and inclinometry (Schlumberger, 1986). This technique was used aboard ship and produced statistically reliable results over limited intervals. FMSDIP, a new technique, takes full advantage of the lateral continuity of the FMS data by using all 64 conductive traces (Antoine and Delhomme, 1989). Based on event detection in the images, this method tracks and maps lateral continuity (known as flowlines) on each trace and correlates these flowlines between each pad to recover the complete path of the feature around the borehole. The second technique appears to be more accurate and robust for identifying fine laminated bedding, even in the presence of steep fractures. As with any automatic technique, however, its reliability and accuracy depends on the quality of the images and the lithologies encountered. Unreliable results calculated with this method were deleted from the final data given in this study.

\section{Results}

\section{Site 829}

The first attempt to determine bedding orientation and planar structures, such as fractures and fault planes observable on the FMS 


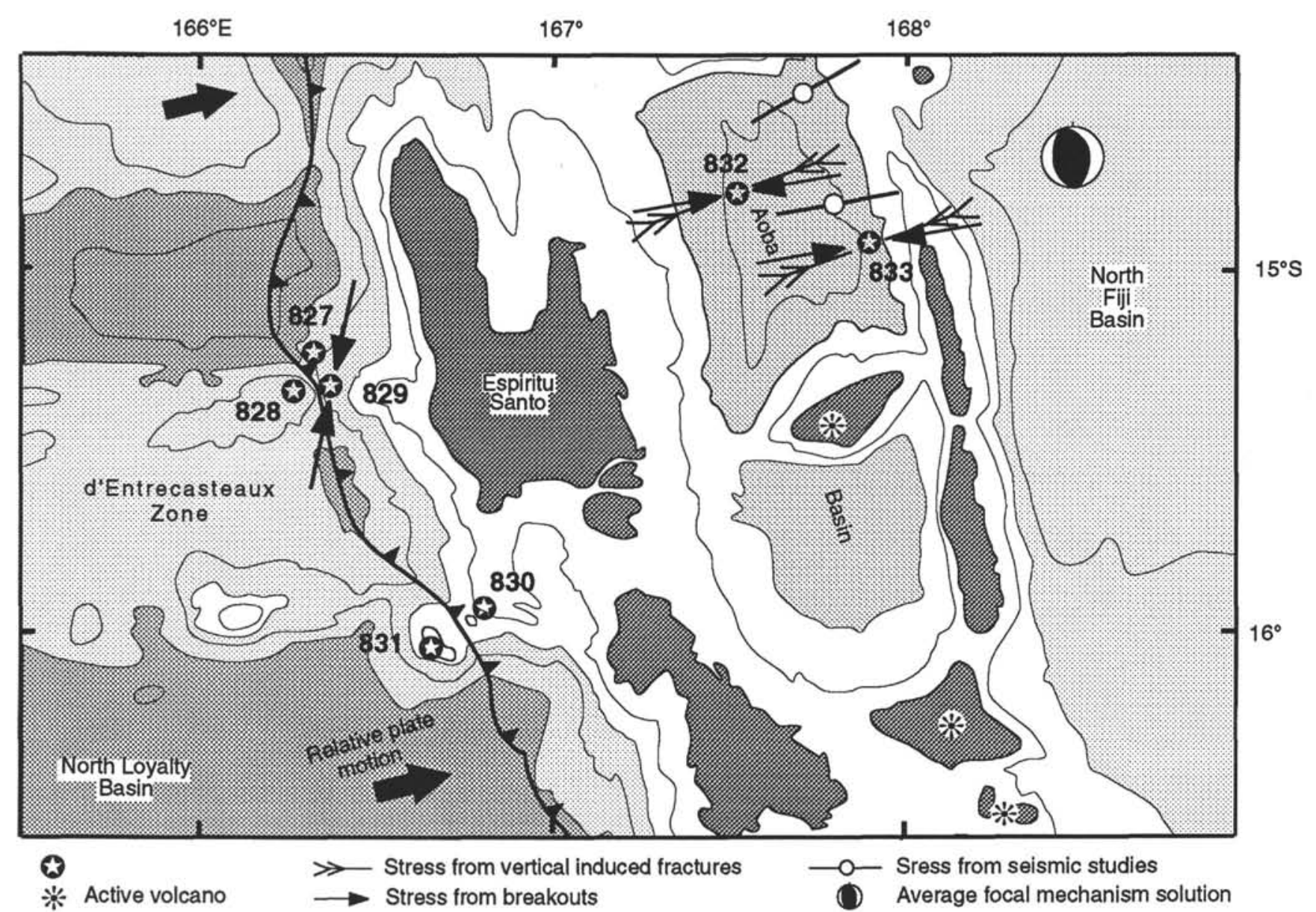

Figure 1. Location map of drilled sites in the central New Hebrides Island Arc. Result of stress analysis from breakouts, observed fractures, and seismicity studies are summarized.

images at Site 829 , was only moderately successful because of several factors:

1. In the upper section of the hole, the diameter exceeds 14 in. ( 35 $\mathrm{cm}$ ), which prevents the pads from making proper contact with the borehole wall. In such an interval the FMS image remains black (high conductivity), even after image enhancement.

2. In intervals where bedding is poorly defined, as in Hole 829A, the automatic determination approach is inefficient because the lack of high-gradient transition layers produces inaccurate bed boundaries. The highly deformed structure of the accretionary complex (sheared sedimentary breccia with deformed chalk and volcanic siltstone) also considerably reduced the lateral continuity of the images. Thus, few flowlines could be computed for each trace and the pad-to-pad correlation was poor. Nonetheless, about 400 planar structures were automatically identified and computed. Their dip and strike, with no differentiation of structure type, are plotted in Figure 2. Although scattered, the average orientation is east, as indicated by the $81^{\circ} \mathrm{W}$ orientation of the mean vector of their pole (concentration factor $\mathrm{k}=$ 6.8 and $95 \%$ confidence cone $=2.7^{\circ}$ ). This result confirms the first on-board estimate (Collot, Greene, Stokking, et al., 1992) and is consistent with the eastward-dipping direction of the subduction zone.

Conductive structures interpreted as small faults, thrust faults, and fractures were also mapped independently using an interactive workstation and are displayed in Figure 2 and on the stereographic projection presented in Figure 3. Three sets of structures were identified according to their average orientation. The oriented structures identi- fied in the first set dip between $25^{\circ}$ and $65^{\circ}$ toward $\mathrm{N} 67^{\circ} \mathrm{E} \pm 20^{\circ}$ and are interpreted as thrust faults. The second set contains fewer structures that strike northeast. The southeast-dipping structures correspond to a major fault zone at 260 meters below seafloor (mbsf), and the other structures, along with those of the third set, are found in the large shear zones between 380 and 460 mbsf. The orientation of the thrust faults of Set 1 also indicates that the dip angle of thrust sheets decreases downhole from $60^{\circ}$ at $260 \mathrm{mbsf}$ to about $20^{\circ}$ or less at $460 \mathrm{mbsf}$.

The FMS images helped to identify and locate thrust faults and shear zones (Meschede and Pelletier, this volume), which were identified in cores or could be inferred from structural analyses. Fault zones at Site 829 are generally associated with borehole deterioration, consecutive to drilling disturbance. As a result of the intense tectonic deformation along the major thrust zones during the arc-ridge collision, cataclasites that characterize the shear bands are easily disturbed and removed during and after drilling. The resulting borehole degradation and enlargement in such zones produce peaks in the caliper logs recorded with the FMS (Fig. 2). FMS electrical measurements are poor in the shear bands as mentioned before, but they provide information about orientation and thickness, which varies from a few centimeters to more than $5 \mathrm{~m}$ at $390 \mathrm{mbsf}$. Figure 4 shows an eroded shear band whose presence was suggested by the highly brecciated rocks resulting from brittle deformation observed between 259 and $260 \mathrm{mbsf}$; the existence of this band was confirmed by the FMS. The thrust-fault orientation (dipping $50^{\circ}$ toward $\mathrm{S} 70^{\circ} \mathrm{E} \pm 10^{\circ}$ ) is determined from the sharp boundaries between the cataclasite, which appears dark on the image, and the surrounding calcareous chalk. Although no change in lithology across the fault was indicated by the cores, other logs, or FMS 


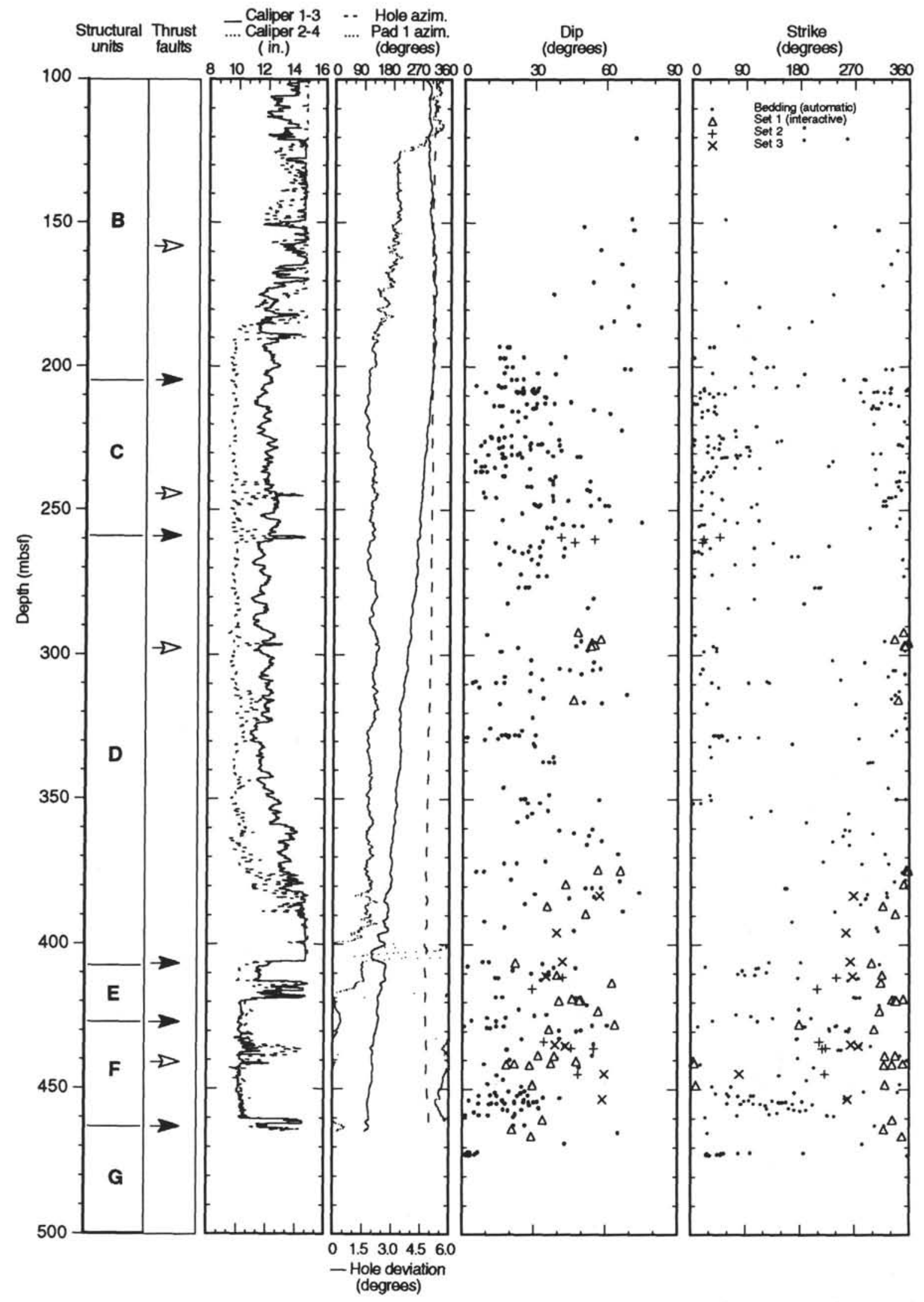

Figure 2. Summary chart of the borehole geometry and planar features recorded with the FMS at Site 829. Columns 3 and 4 display the borehole diameter variation with depth in two orthogonal directions. The orientation of caliper 1 is shown in column 3 (dashed line) with the trend of the borehole relative to the north (dotted line) and its drift (solid line). The last two columns display the orientation of planar features estimated from the FMS images. Solid dots represent all features calculated automatically (FMSDIP program) with no type differentiation. The other symbols correspond to fractures and faults that are differentiated according to their type and strike. 


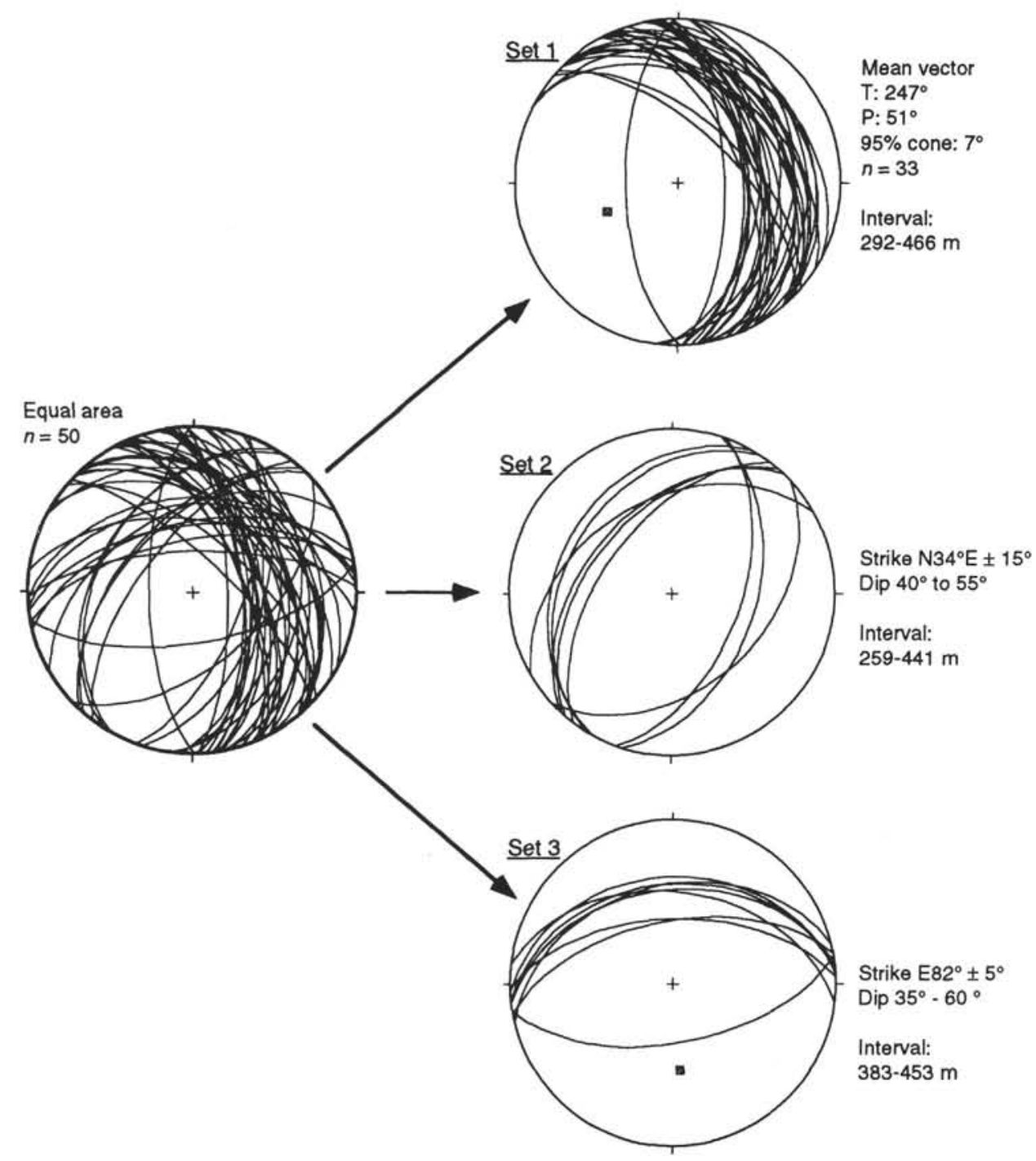

Figure 3. Hole 829A. Stereographic projection of fracture planes mapped interactively on FMS images. Three subsets of different orientation are identified.

images, the formation is slightly more resistive (lighter) below the fault than above. This change in resistivity is associated with increases in velocity and calcium content. Because no significant change is seen in other logs or in the borehole size, this resistivity anomaly probably results from a decrease in water content below the fault. Shear dewatering was observed in other shear zones identified from the cores (Collot, Greene, Stokking, et al., 1992). Although the FMS data do not provide direct information concerning water content at the thrust-fault zone, the degradation of the borehole near the fault may indicate that water content and porosity are much higher at the fault level than above or below it. This provides additional evidence that thrust faults direct fluid flow and that shear dewatering occurs in the accretionary complex, as is the case in Barbados (Taylor and Leonard, 1990).

\section{Site 832}

Bedding orientations computed from FMS data at Sites 832 and 833 were compared with measurements from cores and reoriented with paleomagnetic data. Table 1 shows the agreement between the two independent measurements and proves that major block rotation did not occur after the sediments were deposited. General variations of the bedding and structural features mapped interactively from FMS images (Fig. 5) reflect precisely the lithostratigraphic units defined by the cores.

The boundary between the basaltic breccia interbedded with volcanic sandstones from structural Unit $\mathrm{C}$ and the subhorizontal laminated limestones with clay from Unit $\mathrm{D}$ is clearly marked by a change in the bedding orientation (Figs. 5 and 6 ). Above 700 mbsf the bedding is poorly defined and characterized by abundant slumps, dipping from $20^{\circ}$ and $60^{\circ}$ to the northwest. It becomes subhorizontal with a northeast to southeast dipping direction in structural Unit D. This change in bedding demonstrates the existence of an angular unconformity at $706 \mathrm{mbsf}$, according to other geophysical logs.

The very well laminated bedding of structural Unit D also contrasts with the inhomogeneous attitude of Unit $\mathrm{C}$ bedding, and clearly shows a change in the sedimentation. Although strikes of the bedding in Unit D are inaccurately estimated because of the low dip values, the average strike of north-northwest to north-northeast shows that the entire sequence of structural Unit D was tilted eastward $\left(<10^{\circ}\right)$. Because this sequence is early to late Pliocene in age, a maximum age of late Pliocene to early Pleistocene can be inferred for the beginning of the east-west compression regime.

In structural Unit $D$, the bedding, which is almost flat from 702 to $745 \mathrm{mbsf}$, increases up to $30^{\circ}$ at $755 \mathrm{mbsf}$ and regularly decreases 


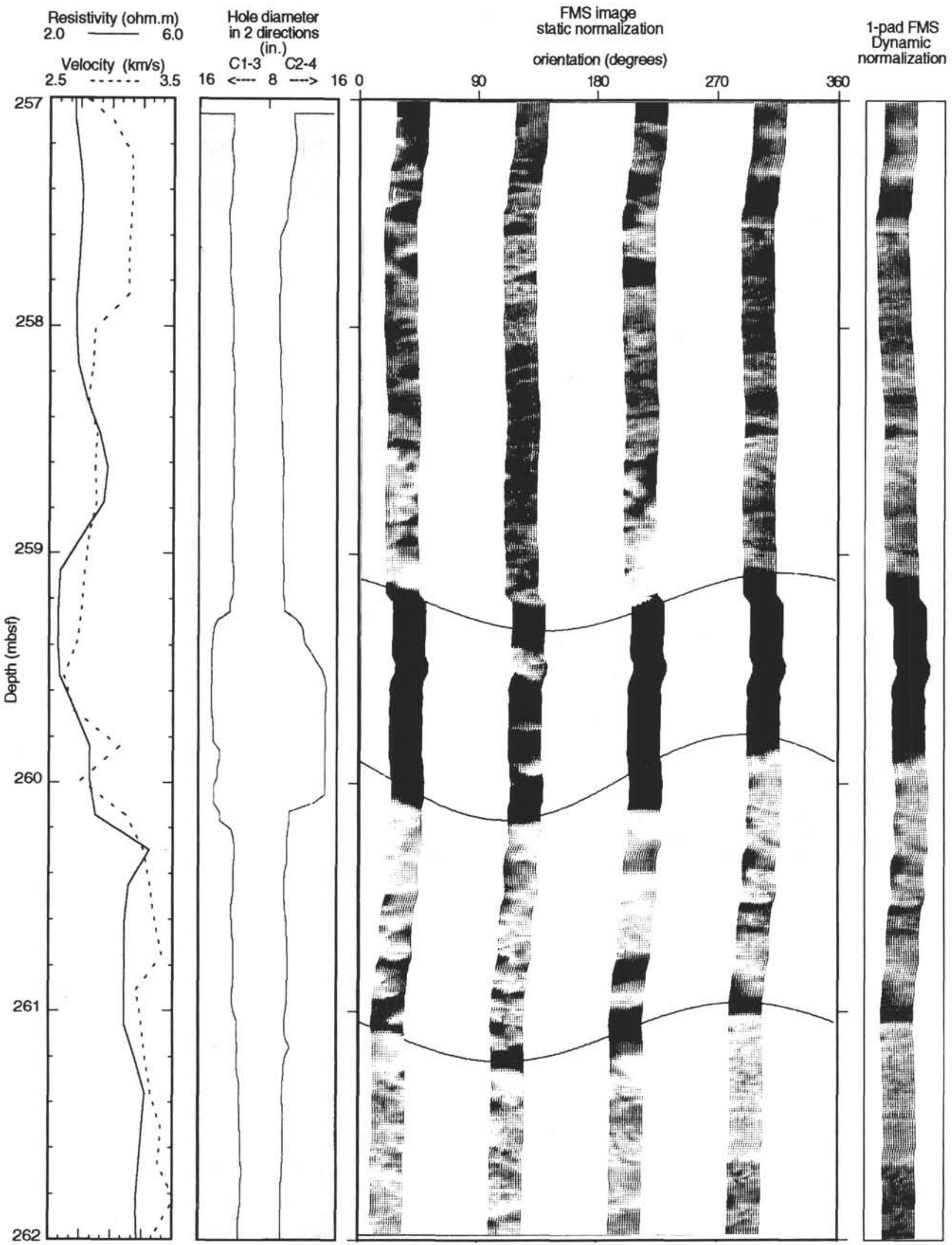

Figure 4. FMS-oriented image of a major thrust fault zone $\left(50^{\circ} \mathrm{ESE}\right)$ characterized by a local borehole enlargement at Site $829 \mathrm{~A}$. Change in gray scale across the thrust fault indicates a resistivity increase downhole (lighter) that correlates with an increase in velocity and calcium content. Dynamically enhanced trace on the right shows that the sedimentary rocks are the same above and below the fault. 
Table 1. Bedding orientation from FMS and cores.

\begin{tabular}{lclrrrr}
\hline Site & $\begin{array}{c}\text { Structural } \\
\text { unit }\end{array}$ & $\begin{array}{c}\text { Type } \\
\text { of data }\end{array}$ & $\begin{array}{c}\text { Number } \\
\text { of points }\end{array}$ & $\begin{array}{c}\text { Dip } \\
\text { direction } \\
\text { (degrees) }\end{array}$ & $\begin{array}{c}\text { Dip } \\
\text { angle } \\
\text { (degrees) }\end{array}$ & $\begin{array}{c}99 \% \text { cone } \\
\text { confidence } \\
\text { (degrees) }\end{array}$ \\
\hline 829 & B-E & FMS auto. & 396 & 90.0 & 9.0 & 3.6 \\
832 & D & Core & 19 & 100.0 & 6.0 & 5.7 \\
832 & D & FMS int. & 230 & 95.0 & 5.0 & 1.0 \\
832 & E VI & FMS int. & 56 & 49.0 & 12.0 & 6.9 \\
832 & E VII & FMS int. & 69 & 181.0 & 8.0 & 13.0 \\
833 & B & Core & 46 & 218.0 & 7.0 & 5.8 \\
833 & B & FMS int. & 25 & 217.0 & 22.0 & 5.8 \\
833 & B & FMS auto. & 358 & 239.0 & 14.0 & 1.0 \\
833 & C & Core & 129 & 261.0 & 8.0 & 3.6 \\
833 & C & FMS int. & 93 & 250.0 & 19.0 & 5.7 \\
833 & C1 & Core & 100 & 261.0 & 10.0 & 2.6 \\
833 & C1 & FMS auto. & 1341 & 251.0 & 13.0 & 0.5 \\
833 & C2 & Core & 29 & 257.0 & 3.0 & 14.0 \\
833 & C2 & FMS auto. & 61 & 261.0 & 20.0 & 8.1 \\
833 & D & Core & 14 & 279.0 & 21.0 & 5.1 \\
833 & D & FMS int. & 41 & 249.0 & 24.0 & 5.0 \\
& & & & & &
\end{tabular}

Note: Core measurements are corrected using paleomagnetic data. Orientations from FMS results generated by interactive mapping of bedding planes (FMS int.) using an image analysis workstation and from automatic computation (FMS auto.) using FMSDIP routine (Schlumberger).

back to subhorizontal at 780 mbsf and below. Variations in the dip angle are associated with a progressive rotation of the bedding strike from about $\mathrm{N} 30^{\circ} \mathrm{W}$ in the flat section to $\mathrm{N} 40^{\circ} \mathrm{E}$ at its highest dip value, and back to a north-northwest direction below $780 \mathrm{mbsf}$. Drag zones produced by thrust faults in relatively unconsolidated sediments usually produce similar variation patterns. The existence of a series of faults striking $\mathrm{S} 50^{\circ} \mathrm{W} \pm 10^{\circ}$ and dipping $30^{\circ}-60^{\circ}$ to the northwest supports this hypothesis. The relatively high dipping angle of the faults suggests that faulting occurred before tilting, and the faults' orientation indicates a maximum horizontal paleostress of northwestsoutheast, clearly different from the east-northeast contemporary compressive stress estimated from seismicity, breakouts, and vertical fracture analysis (see "Stress Analysis" section, this chapter). The impingement of the d'Entrecasteaux Ridge may be responsible for the change in the compression direction.

In the same interval, $740-770$ mbsf, core observations reveal abundant conjugated microfaults striking north-northwest-southsoutheast to northeast-southwest (Pelletier et al., this volume) that are barely detected by the FMS. Inversely, very few faults mapped from FMS images were observable on cores. The agreement between the bedding attitudes estimated from the FMS and those from the cores confirms that the reorientation is correct (Table 1). This demonstrates the complementarity of both techniques, and it indicates that each fault population corresponds to different tectonic events. The normal microfaults, which result from the compaction caused by the sediment column, do not show high resistivity contrast, whereas reverse faults with wider apertures probably filled with water have a strong conductive signature.

\section{Site 833}

Both automatic and interactive dip determinations were used at Site 833 because the first method, which produced good results for the bedding orientation $\left(10^{\circ}\right.$ to $20^{\circ}$ toward $\left.570^{\circ} \mathrm{W}\right)$ in the volcanic sandstones and limestones of structural Units B and C, was inefficient in recognizing structural features present in the bottom interval. Figure 7 shows extremely regular bedding from 558 to $762 \mathrm{mbsf}$, interrupted only between 746 and 750 mbsf by a series of microfolds, with axes plunging $6^{\circ}$ toward $\mathrm{S} 36^{\circ} \mathrm{W}$ (Fig. 8).

A major change in the attitude of the bedding and the deformed structures occurs below 762 mbsf within structural Unit C (Figs. 7 and 9). Above a 20 -cm-wide fault zone $\left(40^{\circ} \mathrm{W}\right)$ at $762 \mathrm{mbsf}$, the bedding dips slightly $\left(20^{\circ} \mathrm{W}\right)$ and consists of the calcareous mixed sedimentary rock. Below the fault the silty chalk exhibits two sets of steep fractures $\left(50^{\circ}-80^{\circ}\right)$ with azimuth of $\mathrm{N} 60^{\circ}-80^{\circ} \mathrm{E}$ and $\mathrm{N} 60^{\circ}-$ $90^{\circ} \mathrm{W}$. These fractures are a few centimeters wide and locally produce borehole degradation as they intersect each other. This fracture zone separates the upper interval of Unit $\mathrm{C}$, which is characterized by a well-defined bedding that gently dips to the west-southwest, and the lower interval, with bedding plane dips that range from $20^{\circ}$ to $60^{\circ}$.

Several steep faults striking east-southeast were mapped between 625 and 703 mbsf on the FMS images that correspond to the abundant normal faults observed in cores from structural Subunit C1, indicating a north-northeast-south-southwest extension. However, abundant steep north-northwest-striking faults, consistent with the tectonic compressive stress, are also present in the FMS images in structural Unit C, but they could not be identified on cores (Fig. 10). As was the case with Site 832 , the FMS tended preferentially to record structural features related to compressive stress, which are generally poorly recovered in cores, but it failed to image small displacements resulting from extension because of the low surface coverage of the borehole wall.

In the bottom section of the Hole $833 \mathrm{~B}$, the presence of basaltic sills is clearly identified by the absence of bedding and the abundance of scattered fractures. The upper section of the intrusion is relatively uniform over its depth ( $828-875 \mathrm{mbsf}$ ), although few thin conductive layers (about $1-\mathrm{m}$ thick) can be seen at $837,839,854$, and $858 \mathrm{mbsf}$. They correspond to intervening clayey calcareous volcanic sandstones like those found in Core 134-833B-84R. The first appearance of the second basalt intrusion is found at $909 \mathrm{mbsf}$, but thin sections of sedimentary rocks are still present to 918 mbsf. The basaltic sill is composed of a network of very conductive fractures dipping from $10^{\circ}$ to $>80^{\circ}$, which are apparently oriented randomly. The orientation of these fractures is uncertain, however, because the orientation of the FMS tool computed by a 3-axis magnetometer is highly perturbed in the magnetic sills. The total field recalculated from the three-component magnetometer varies from $25 \times 10^{3} \mathrm{nT}$ to $50 \times 10^{3} \mathrm{nT}$ in the upper sill, although it is almost constant at $44 \times 10^{3} \mathrm{nT}$ in the sediment column above it. A simple azimuthal correction of the orientation of the fractures, assuming a straight motion of the tool with no rotation, does not seem to affect the apparent random distribution in the sill units. Thus, the origin of the basement fractures cannot yet be related to present or past tectonic stresses.

The bedding above and below the sill maintains a constant northsouth strike but the dips decrease regularly from $70^{\circ} 40 \mathrm{~m}$ above the sill, to an almost flat horizon at the contact between the sedimentary rocks and the basalt. Between the sill intrusions, the same pattern was observed (Fig. 11). The dip of the subhorizontal bedding in the vicinity of the sills increases regularly moving away from them, reaching $60^{\circ}$ between the two intrusion sheets. The south-southeast dipping direction of the beds remains constant.

Whether the basalt intruded the sediments before or after the sediments were tilted cannot be determined from the FMS data alone. At least two possible scenarios can be envisioned:

1. The magmatic intrusion occurred within already tilted sediments. In that case, the concordance in dip and azimuth of the bedding immediately above and below the sills suggests a horizontal magmatic intrusion that requires the pre-existence of a horizontal fracture. The magma, injected horizontally, expanded vertically and created a deformation associated with the compaction of the surrounding sediments.

2. In the second scenario, the magma intruded the unconsolidated sediments parallel to the bedding, creating in the vicinity of the basaltic sills more compacted and indurated sediments, as shown by the increase in density log. Because of the higher strength of the sills and the sediments surrounding the sills, the tilting is greater at a distance away from the sills and decreases moving toward the intrusion.

The Pliocene age of basalt sills, estimated by $\mathrm{K}$-Ar radiochronologic dating, indicates that the intrusion is almost contemporary or 

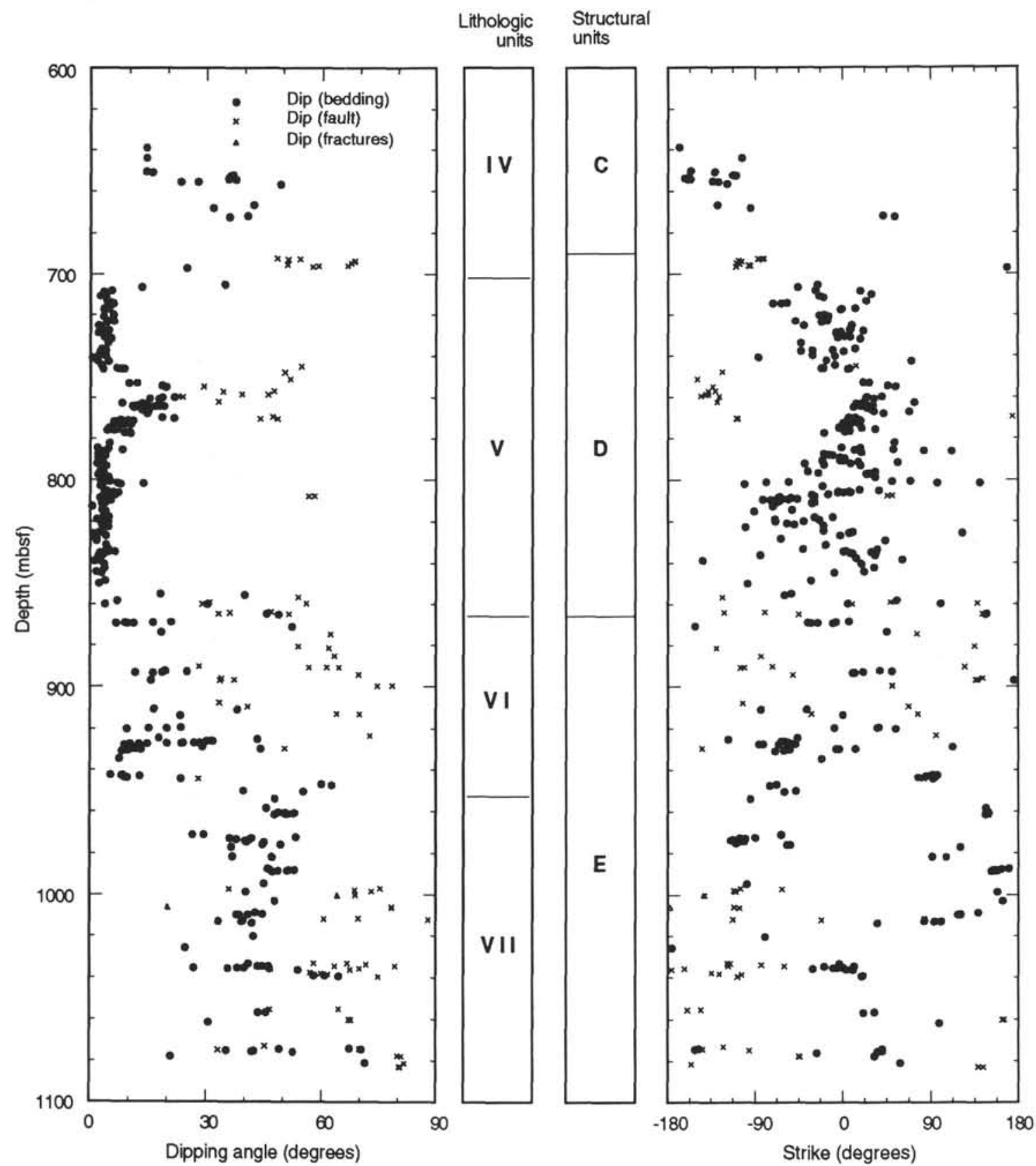

Figure 5. Dips and strikes of planar features interactively mapped from FMS images at Site 832. Solid dots correspond to the bedding planes, and crosses represent all types of faults and fractures. The change in bedding attitude correlates with lithostratigraphic boundaries.

slightly postdates the sedimentary deposition of lower Pliocene. This result favors the second scenario and constrains the westward-tilting event caused by the east-northeast-west-southwest compressional regime, which is associated with an uplift of the eastern part of the basin and is of late Pliocene age at the earliest.

\section{STRESS ANALYSIS}

\section{Methods}

Whether recorded by four-arm caliper tools, dipmeters, acoustical borehole televiewers, or the FMS, borehole elongations have been interpreted as breakouts and have been shown on the basis of independent stress measurements to be reliable indicators of horizontal principal-stress direction (Plumb and Hickman, 1985; Hansen and
Purcell, 1989; Mastin et al., 1991). In their detailed studies of crosssectional shape of breakouts recorded with the ultrasonic borehole televiewer tool, Zoback et al. (1985) suggest that breakouts result from shear failure where the elastic shear stress around the borehole exceeds the shear strength of the rocks. The observation and analysis of borehole elongation using the BHTV are presented in Krammer and Chabernaud (this volume). I will focus here on the analysis of images obtained by the FMS tool. Because the borehole coverage of the ODP version of the FMS tool is only about $25 \%$ of the total circumference, the exact borehole shape is not known.

Nonstress-related borehole elongations such as drill-pipe wear or washouts can be misinterpreted as breakouts. Plumb and Hickman (1985) showed that breakouts can be differentiated from washout zones or asymmetric elongations caused by drill-pipe wear, providing a set 


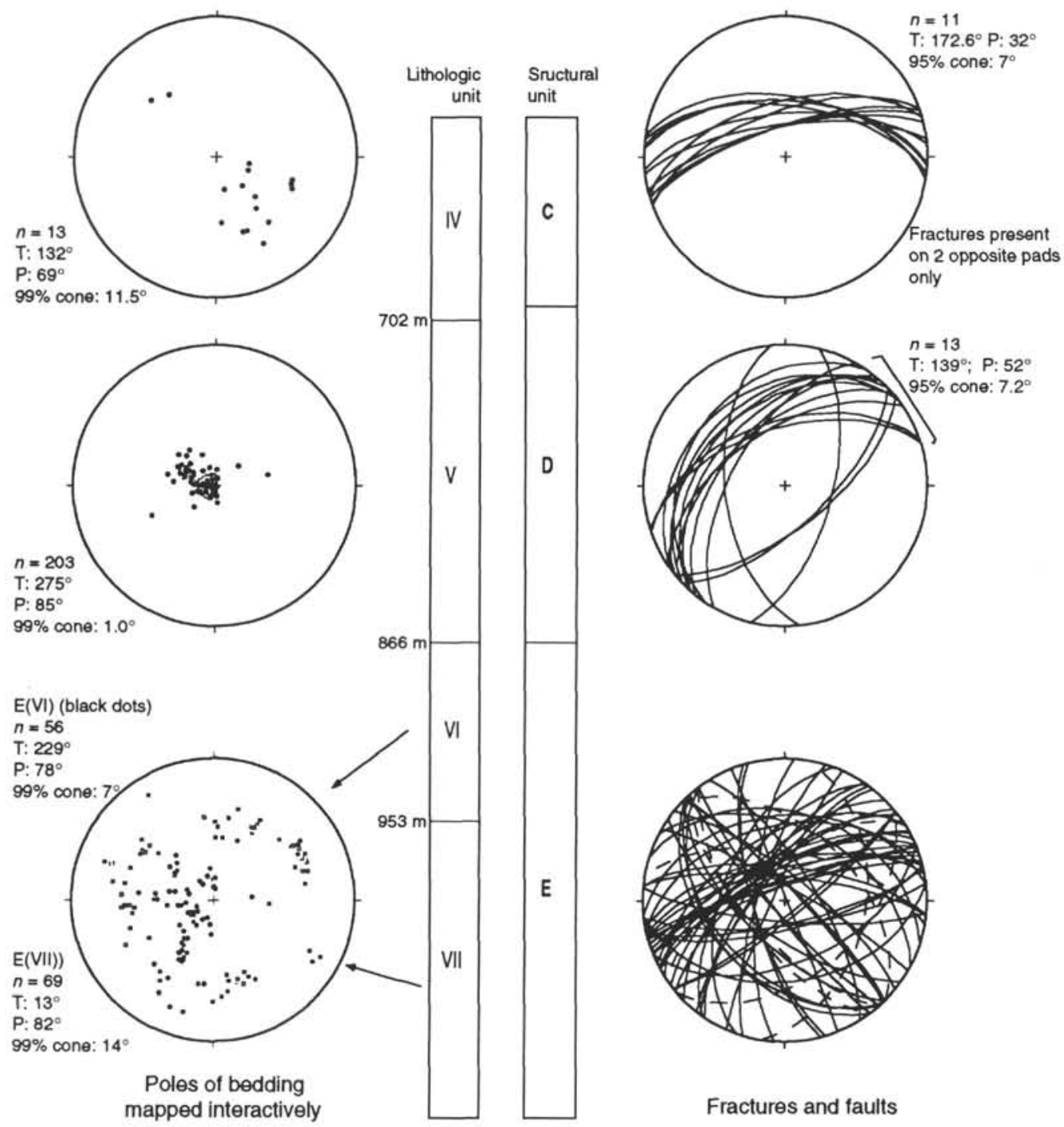

Figure 6. Stereographic projection of poles of bedding and planes of fractures and faults mapped on FMS images at Site 832. The statistical results of mean vectors are presented in Table 1.

of criteria used with success for their study (for an 8.5-in.-diameter hole): (1) the elongation must be $>0.6 \mathrm{~cm}$ (e.g., the difference in caliper readings in perpendicular directions); (2) the zone of elongation should be $>30 \mathrm{~cm}$; (3) the tool orientation is constant throughout this interval; (4) the smaller of the two caliper readings must be close to the nominal borehole diameter or, if greater, should exhibit less variation than the larger caliper; and (5) the direction of elongation should not coincide completely with the borehole direction of deviation.

To discriminate between breakouts and asymmetric elongation that could verify the above criteria an additional criterion was proposed that implies symmetrical electrical anomalies by the dipmeter tool. These criteria, which apply even stronger constraints on the elongation length ( $1 \mathrm{in}$. or $2.5 \mathrm{~cm}$ ) and the length of the elongation zone ( $>30 \mathrm{~m}$ as suggested by Hansen and Purcell [1989]), can be applied to our study.

Vertical drilling-induced fractures or hydraulic fractures provide another source of horizontal stress indicator. Theoretically, hydraulic fractures are produced when the pressure of drilling fluid in the borehole exceeds the tensile strength of the rocks in which the fractures align in the direction of the horizontal maximum stress (Rummel, 1988; Borm, et al., 1989). Hydraulic fractures are often associated with breakouts, and they appear on the resistive images on one or both sides of the well as small cracks with very low resistivity contrasts that follow a complex vertical path parallel to the borehole axis. These characteristics distinguish hydraulic fractures from natural vertical fractures that are unlikely to be seen in vertical or nearvertical drill holes.

\section{Results}

\section{Hole 829A}

Borehole deformation is clearly determined in the interval between 192 and $375 \mathrm{mbsf}$, indicating an elongation in the direction $\mathrm{S} 65^{\circ} \mathrm{E} \pm 10^{\circ}$ (Fig. 12). This interval consists of soft calcareous chalk and chalk breccia. The direction of the deformation suggests a stress orientation of $\mathrm{N} 25^{\circ} \mathrm{E}$. The borehole elongation seems related to the hole deviation toward $\mathrm{N} 60^{\circ} \mathrm{W}$, which is parallel to the long axis of the borehole. Comparing the borehole cross section with the BHTV, which exhibits an asymmetric elongation (pear-shaped cross section), confirms this. The FMS images in the same interval do not display any particular feature that reveals the stress orientation. No definite conclusion about the stress orientation can be drawn here. Stress 


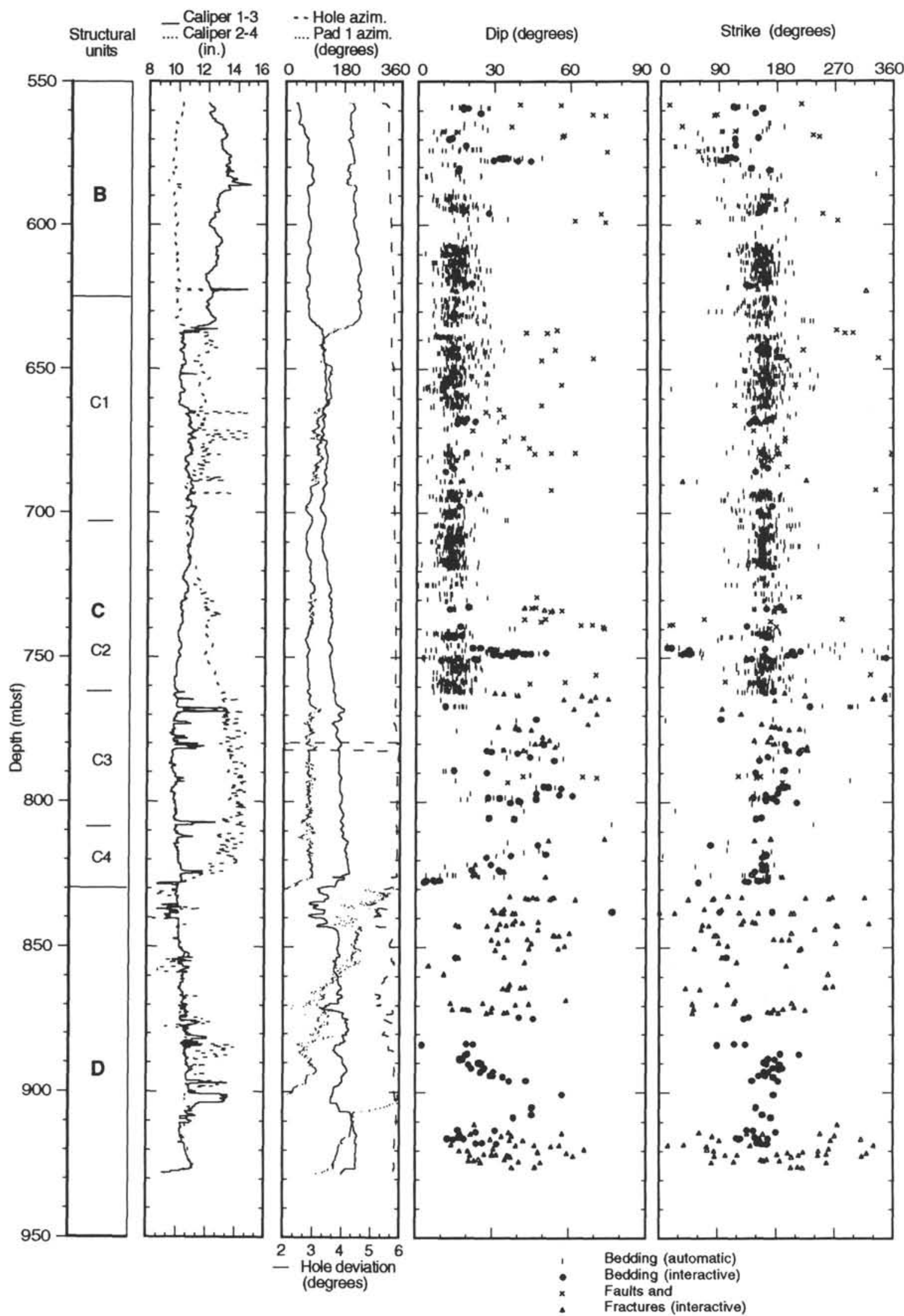

Figure 7. Summary chart of the borehole geometry and planar features recorded with the FMS at Site 833. Columns 3 and 4 display the borehole diameter variation with depth in two orthogonal directions. The orientation of caliper 1 is shown in column 3 (dashed line) along with the trend of the borehole relative to the north (dotted line) and its drift (solid line). The last two columns display the orientation of planar features estimated from the FMS images. Vertical hatch marks represent all features calculated automatically (FMSDIP program) with no type differentiation. Solid dots correspond to bedding planes and other symbols to fractures and faults mapped interactively. 


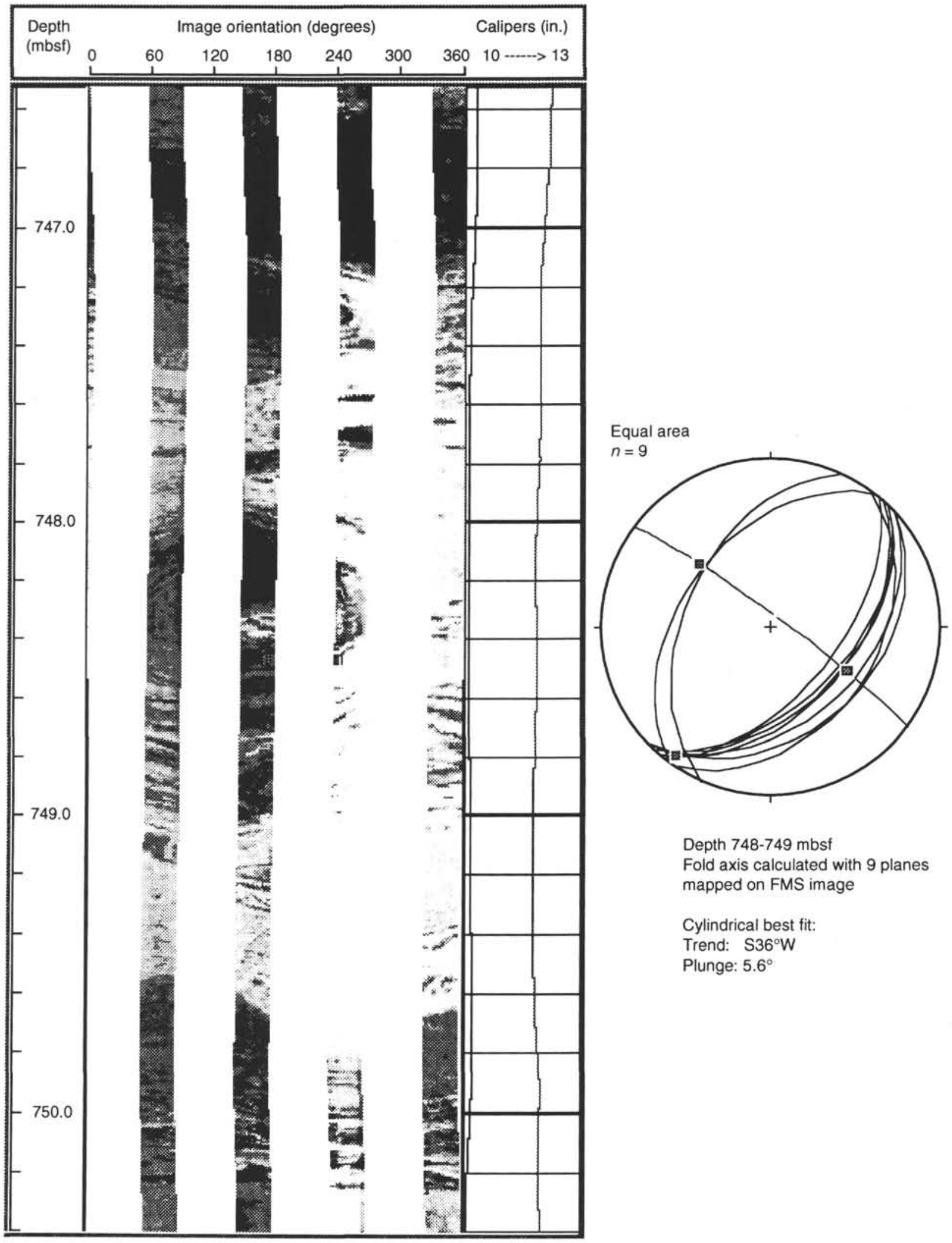

Figure 8. Example of slump microfolds present in mixed volcanic sandstones and silty claystones at Site 833 . The subhorizontal north-northeast-south-southwest fold axis indicates a west-northwest movement that significantly differs from westward bedding dipping direction. 


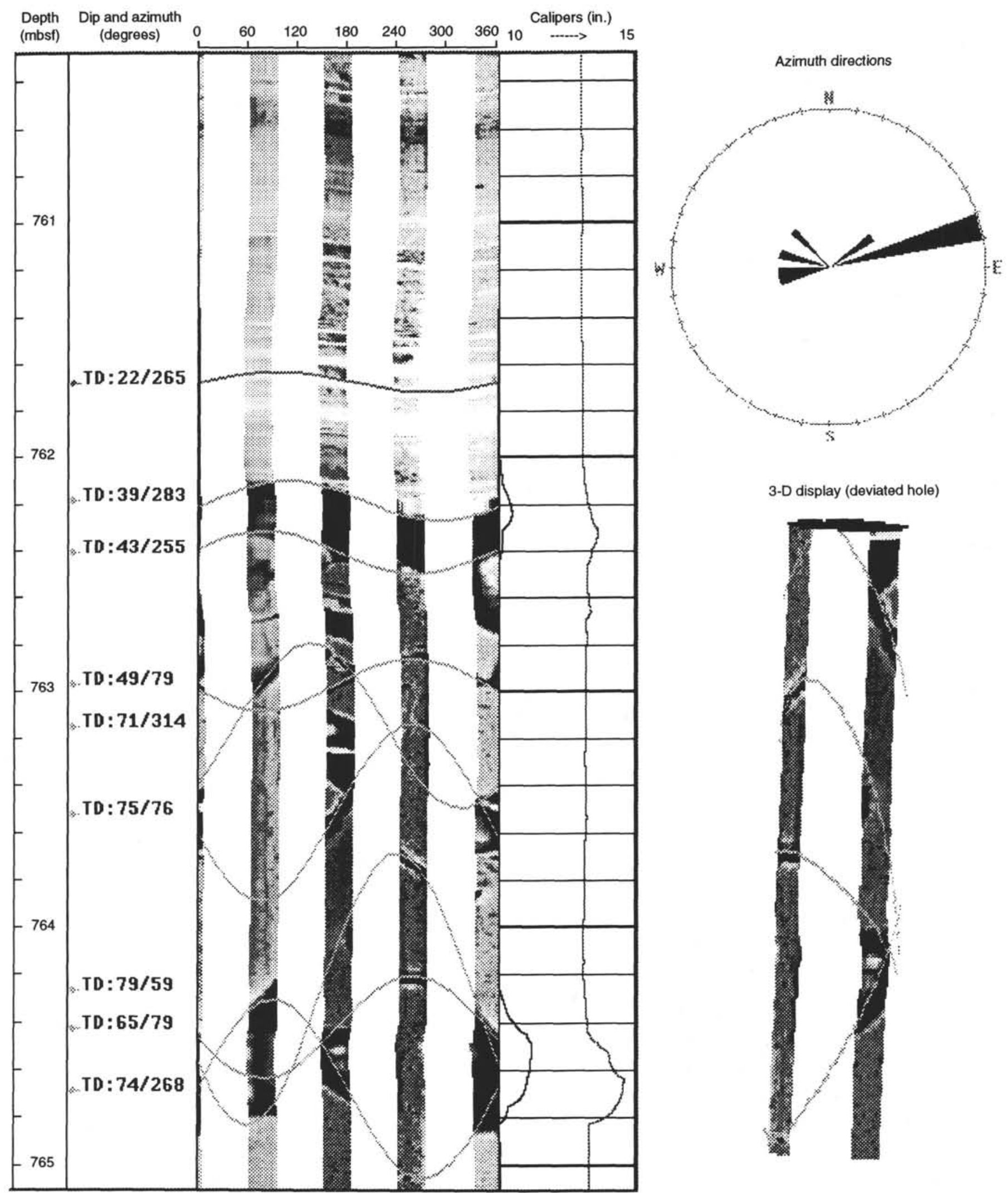

Figure 9. FMS image of the structural boundary at $762.2 \mathrm{~m}$ in Hole 833B. The bedding trace disappears below the west-southwest dipping wide fracture at $762.2 \mathrm{~m}$. 

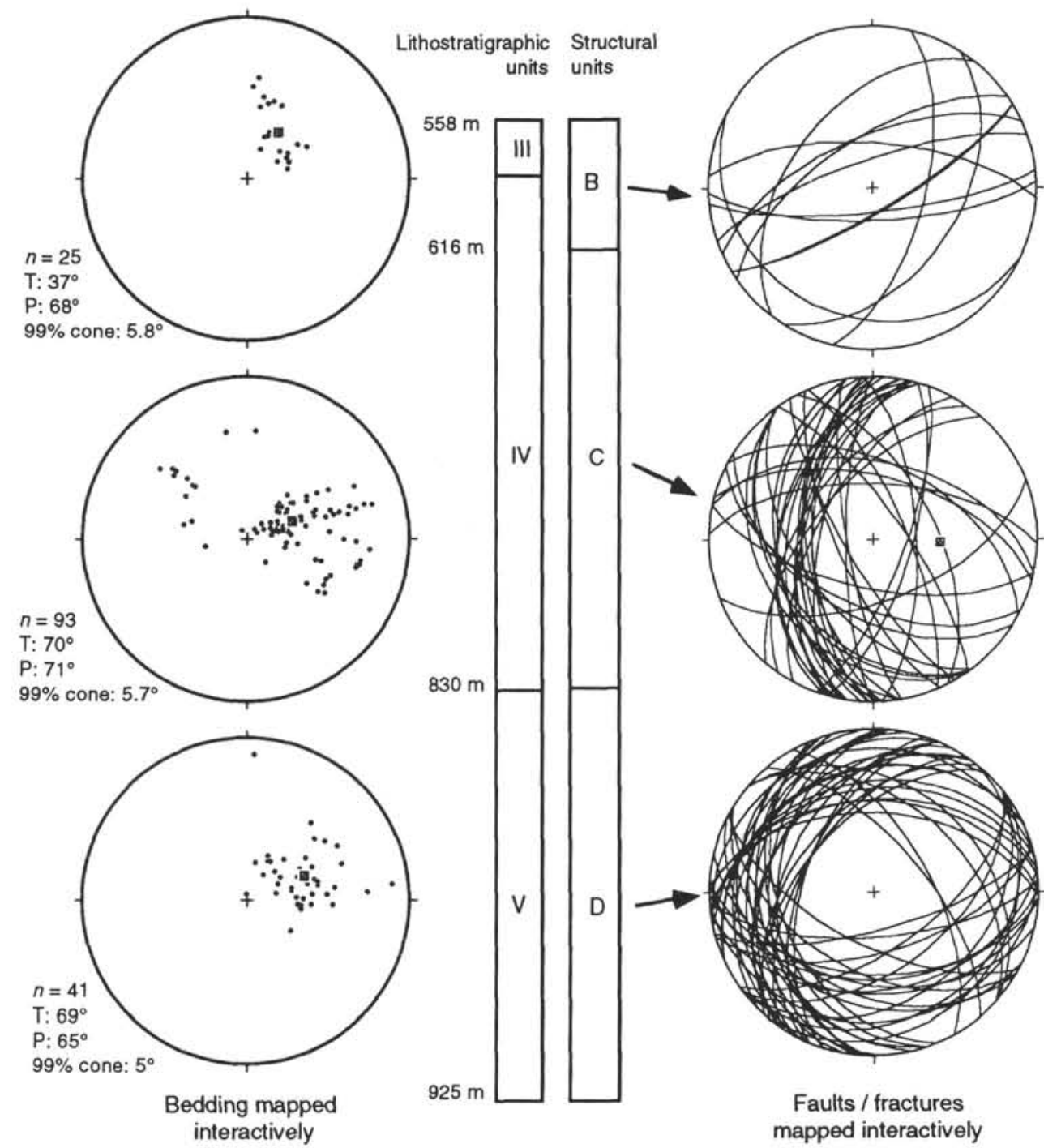

Figure 10. Stereonet of bedding poles and fracture planes mapped interactively from FMS images in different structural units at Site 833

direction, foliation, and thrust sheet orientation, and the pipe deviation that apparently caused the borehole elongation, are likely related. If we assume that the pipe tries to orient perpendicular to the planes it crosscuts, the deviation direction of the hole to the west is easily explained by the eastward-dipping bedding. Furthermore, the decrease of dip angle downhole observed from the FMS-mapped structures also correlates with the decreasing hole-deviation angle. If the borehole elongation were stress related, the north-northeast direction of compression would be consistent with the $\mathrm{N} 76^{\circ} \mathrm{E} \pm 11^{\circ}$ relative plate motion direction $(10 \mathrm{~cm} / \mathrm{yr})$ and the eastward subduction orientation (Fig. 1). The release of stress in an east-west direction caused by thrust faulting would effectively decrease the east-west component of the compressional stress and, thus, would rotate the resulting compressional field to the north.

\section{Hole $832 B$}

The only elongated zone mapped using the two FMS calipers is located between 709 and $772 \mathrm{mbsf}$. The average elongation over that interval is $2.54 \mathrm{~cm}$. The $\mathrm{S} 78^{\circ} \mathrm{E} \pm 5^{\circ}$ orientation suggests a maximum horizontal-stress direction of $\mathrm{N} 12^{\circ} \mathrm{E} \pm 5^{\circ}$ (Fig. 13). This zone, com- posed of silty limestone, is characterized by a subhorizontal bedding that is unlikely to affect the breakout orientation. A concern over the validity of this elongation zone as a breakout candidate arises from the well deviation azimuth, which differs from the elongation direction by only $15^{\circ}$. This suggests that the borehole elongation could result from drill-pipe wear, although the hole deviation from vertical is small $\left(2.5^{\circ}\right)$.

Vertical drilling-induced fractures have been identified in Hole $832 \mathrm{~B}$ in the upper and lower sections of the logged interval, which is composed of basaltic breccia between 640 and $680 \mathrm{mbsf}$, and in the lower unit of basaltic breccia and volcanic sandstones between 920 and 1060 mbsf (Fig. 14). These two sets of hydraulic fractures are consistent and indicate a contemporary principal horizontal stress in the east-northeast-west-southwest direction $\left(\mathrm{N} 70^{\circ} \mathrm{E}\right)$, which is consistent with the $\mathrm{N} 60^{\circ} \mathrm{E}$ compression direction estimated from the $\mathrm{S} 30^{\circ} \mathrm{W}$ anticline axis observed in the northern part of the basin (Daniel et al., 1989).

This condition is supported by the observation of a different kind of drilling-induced fracture observed at the base of the brecciated structural Unit $C$ between 680 and 700 mbsf (Figs. 5 and 6). These fractures are present on two opposite pads, dip $50^{\circ}$ to $70^{\circ}$ and strike 


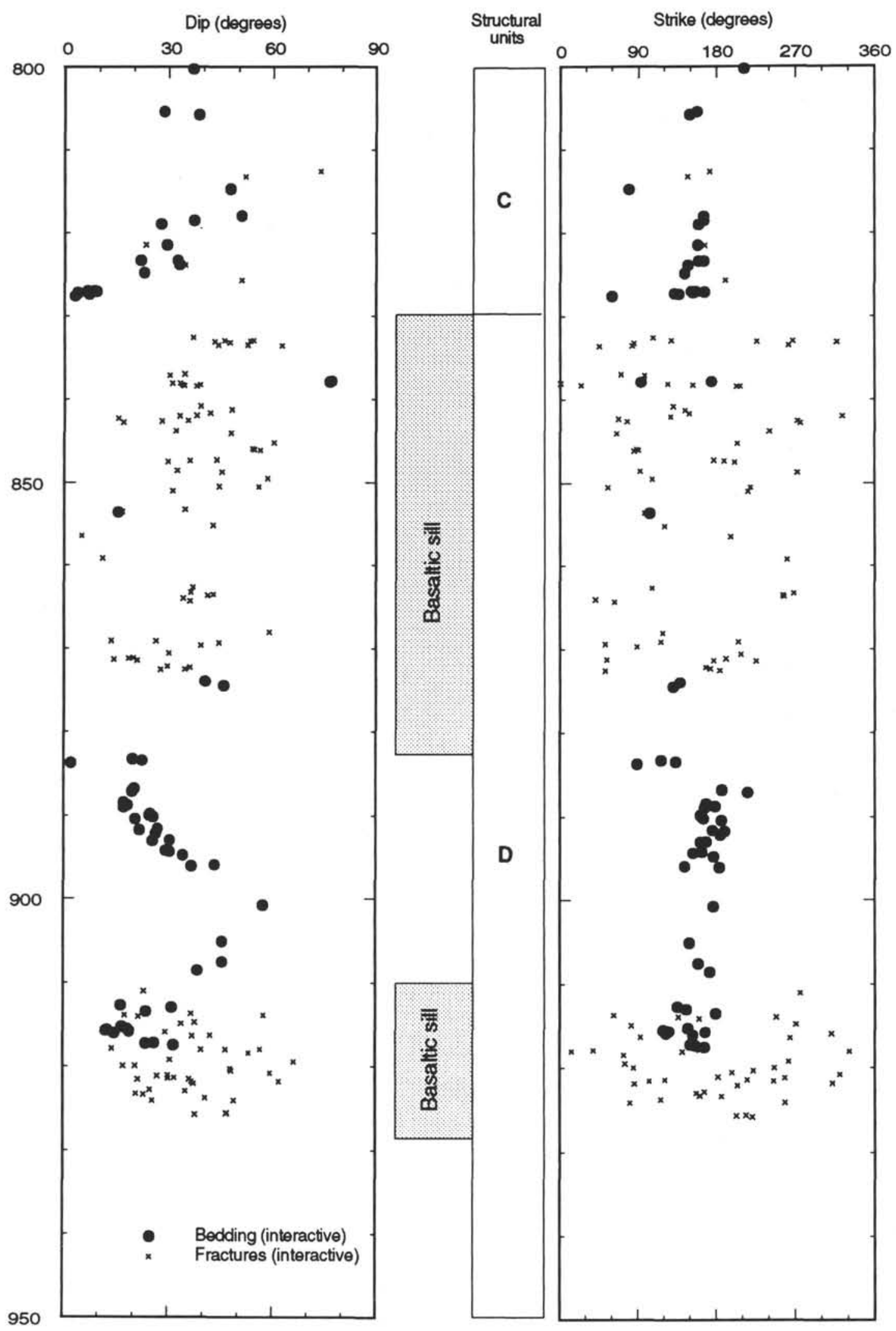

Figure 11. Bedding attitude in the vicinity of the basaltic sills at Site 833 . 


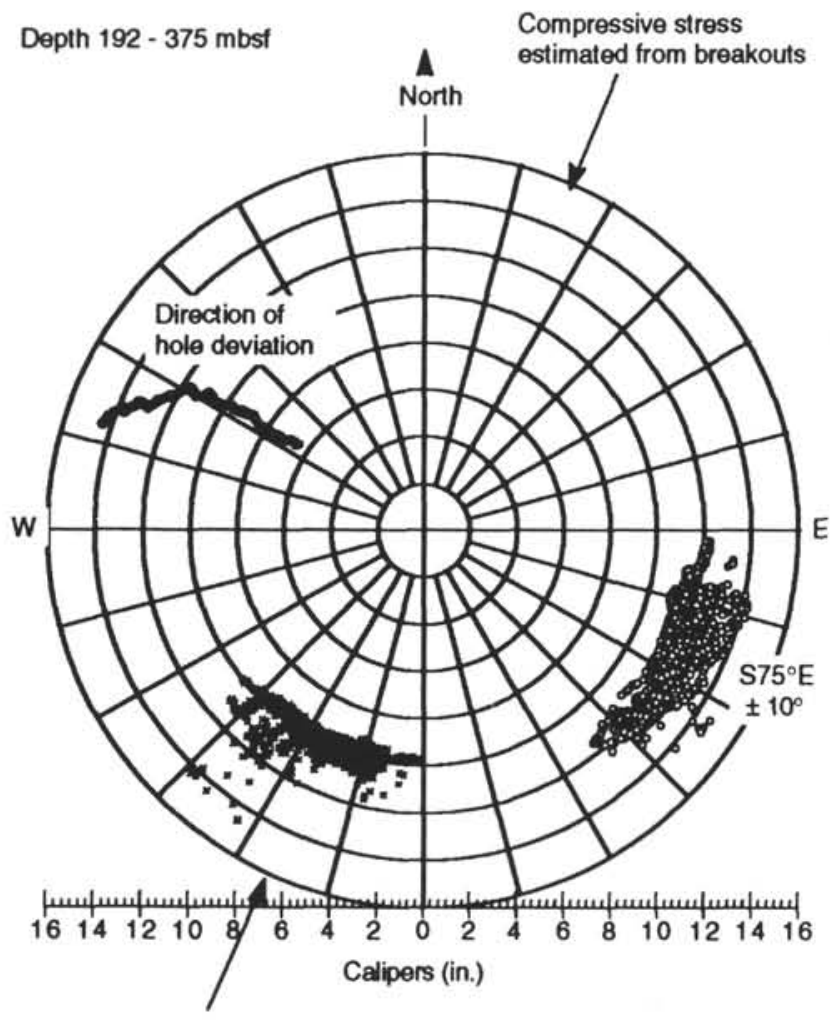

Figure 12. Orientation of borehole minimum and maximum calipers in a selected breakout interval at Site 829 . The horizontal projection of the trend of the borehole (plotted at a different scale) indicates that maximum elongation may result from pipe wear. The compressive stress direction is indicated, assuming that the elongation is stress related.

$\mathrm{N} 83^{\circ} \mathrm{E} \pm 10^{\circ}$, and are interpreted as mixed extension and shear fractures (Bourke, 1989). They are thought to represent incipient breakouts and form normal to the maximal horizontal stress $\left(\mathrm{N} 83^{\circ} \mathrm{E} \pm 10^{\circ}\right)$.

\section{Hole $833 B$}

Vertical drilling-induced fractures at Site 833 are present only in the interval between 783 and 805 mbsf, which consists of mixed sedimentary rocks interbedded with volcanic sandstones and breccias. The constant $\mathrm{S} 70^{\circ} \mathrm{W} \pm 10^{\circ}$ strike of these induced fractures indicates an east-northeast-west-southwest present stress orientation as in Hole 832B, which agrees with the tilting direction of the bedding $\left(\mathrm{S} 70^{\circ}-80^{\circ} \mathrm{W}\right)$, the compression direction $\left(\mathrm{N} 86^{\circ} \mathrm{E}\right)$ estimated from focal mechanism solutions in the Site 833 area (Louat and Pelletier, 1989), and the $S 80^{\circ} \mathrm{E}$ direction of anticlinal ridges, faults, and folds observed on the bathymetric map (Daniel et al., 1989).

Borehole elongation at Site 833 occurs in three depth intervals between 558 and $635 \mathrm{mbsf}, 637$ and $688 \mathrm{mbsf}$, and 718 and $825 \mathrm{mbsf}$. In each case, the difference in caliper reading is $>5 \mathrm{~cm}$ and the borehole drift is $\angle 4^{\circ}$ (Fig. 7). The difference between borehole azimuth and the direction of elongation in the upper two intervals confirms their validity as breakouts oriented $\mathrm{N} 30^{\circ} \mathrm{E} \pm 15^{\circ}$ and indicates a southeast-northwest compression (Fig. 15). In the lower section, however, the elongation coincides with the direction of the borehole deviation indicating that elongation may or may not be stress-related. The compressive stress estimated from the elongation is oriented $N 79^{\circ} \mathrm{E} \pm 8^{\circ}$, in agreement with the $\mathrm{N} 70^{\circ} \mathrm{E} \pm 5^{\circ}$ direction given by vertical fractures and the $\mathrm{N} 86^{\circ} \mathrm{E}$ estimated from seismicity (Fig. 1). Because the validity of the breakouts in the lower section is questionable, appealing results must be viewed skeptically. Breakouts in the upper two intervals, however, fit

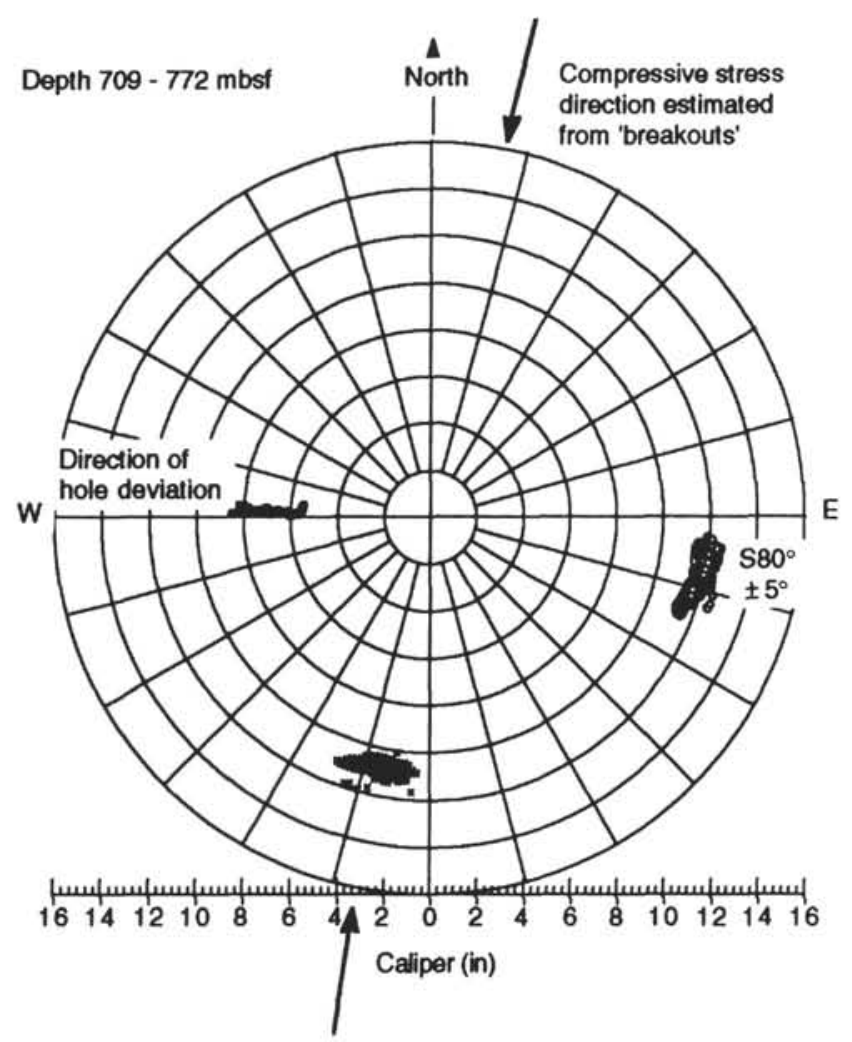

Figure 13. Orientation of borehole minimum and maximum diameters in a selected breakout interval at Site 832 . The horizontal projection of the trend of the borehole (plotted at a different scale) is slightly different from the maximum elongation.

all selection criteria, and the implied $40^{\circ}$ clockwise rotation of stress direction is reliable. Because the orientation of the regional tectonic stress is constant and unlikely to change on a small scale, the observed stress may be a composite field resulting from the superposition of contemporary and perturbing tectonic stresses. Rotations in the breakout direction were similarly supported by hydrofracture measurements and geologic data in the seismogenic area of Moodus, Connecticut (Fang, unpubl. data). In this situation, however, no quantitative external measurements permit us to prove or invalidate the existence and origin of an extensional or compressive perturbing stress field.

\section{CONCLUSION}

The FMS data recorded during Leg 134 show that high-resolution electrical imaging is an efficient means to record in-situ tectonic features. Both interactive and automatic techniques were used to identify and orient the bedding and structures, and both techniques are complementary and necessary for producing an extensive though incomplete structural data set.

Orientations estimated from the images and from the cores after geographic correction with paleomagnetic measurements generally agreed, demonstrating the reliability of both methods. The FMS also provides a continuous record of most of the structures even where core recovery is poor, but fails to resolve very small-scale features seen on cores.

The borehole geometric parameters recorded with the FMS tool can also be used to estimate breakout zones that will yield the orientation of the contemporary compressive stress. This method is efficient in most cases, providing criteria for the validation of borehole elongations related to stress. 
FMS image orientation (degrees)

\begin{tabular}{ccccc}
0 & 90 & 180 & 270 & 360 \\
& 1 & 1 & 1 & 1 \\
\hline
\end{tabular}

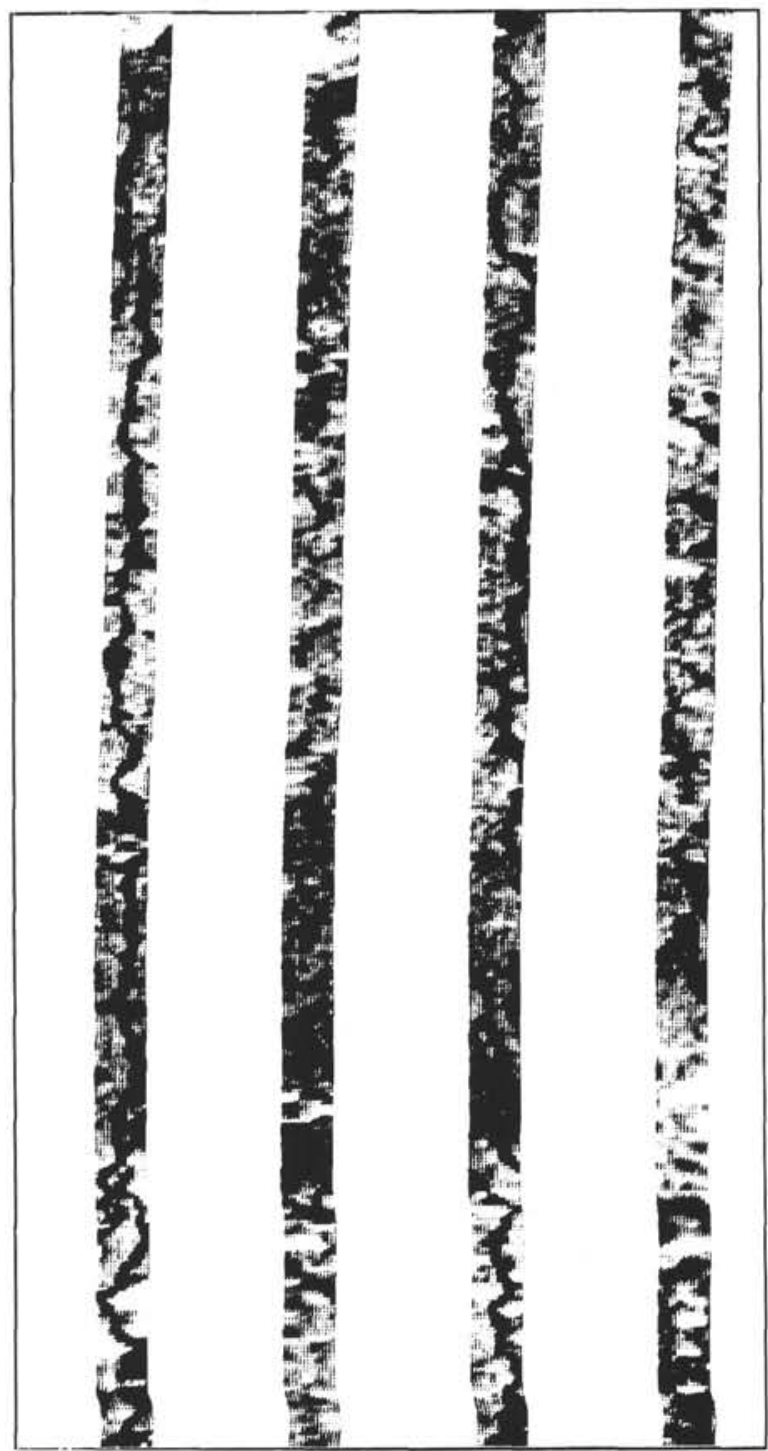

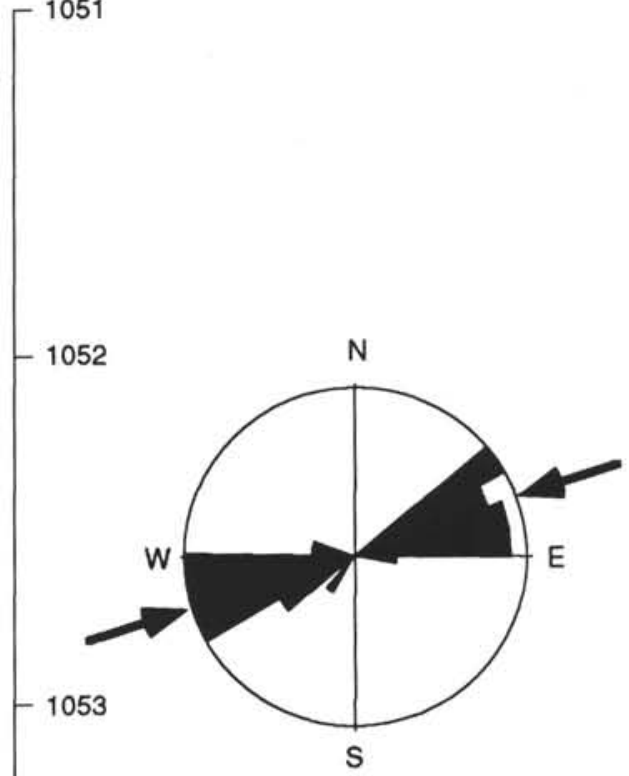

Direction of compressive stress indicated by vertical induced fractures: $\mathrm{N} 70^{\circ} \mathrm{E} \pm 15^{\circ}$ and $\mathrm{S} 60^{\circ} \mathrm{W} \pm 15^{\circ}$

Figure 14. Example of vertical induced fractures observed in the upper and lower part of Hole 832B. The direction of fracture indicates the principal horizontal stress orientation.

Electrical imaging at Site 829 in the accretionary complex of the subduction zone helps to locate and orient the imbricated thrust sheets off-scrapped from the ridge and the arc. Dewatering of the accreted sediments is also suggested by analyses of the images across thrust faults.

The FMS images recorded in the intra-arc North Aoba Basin produced a reliable structural data set that adequately completes and validates core observations. The orientation of the bedding and structural features indicates that the basin has been subjected to horizontal compressive deformation at least since the late Pliocene. Analyses of breakouts and drilling-induced fractures reveal that the contemporary horizontal compression is east-northeast-west-southwest on the eastern flank of the basin (Site 833) and tends to rotate slightly to the northeast-southwest at Site 832B in the central part of the basin. The change of the compression direction probably results from the impingement of the d'Entrecasteaux Ridge, moving to $\mathrm{N} 76^{\circ} \mathrm{E}$, on the New Hebrides Island Arc. Rotation in the breakout orientations at Site 833 also suggests that the flank of the basin is subject to extensional compressional perturbing stress field.

\section{ACKNOWLEDGMENTS}

I wish to thank David Rossi of Schlumberger Doll Research for enabling me to use the FMS image analysis workstation and Phill Frulla for assisting with data analysis. I also thank Bernard Pelletier for useful discussions during the preparation of this manuscript. 

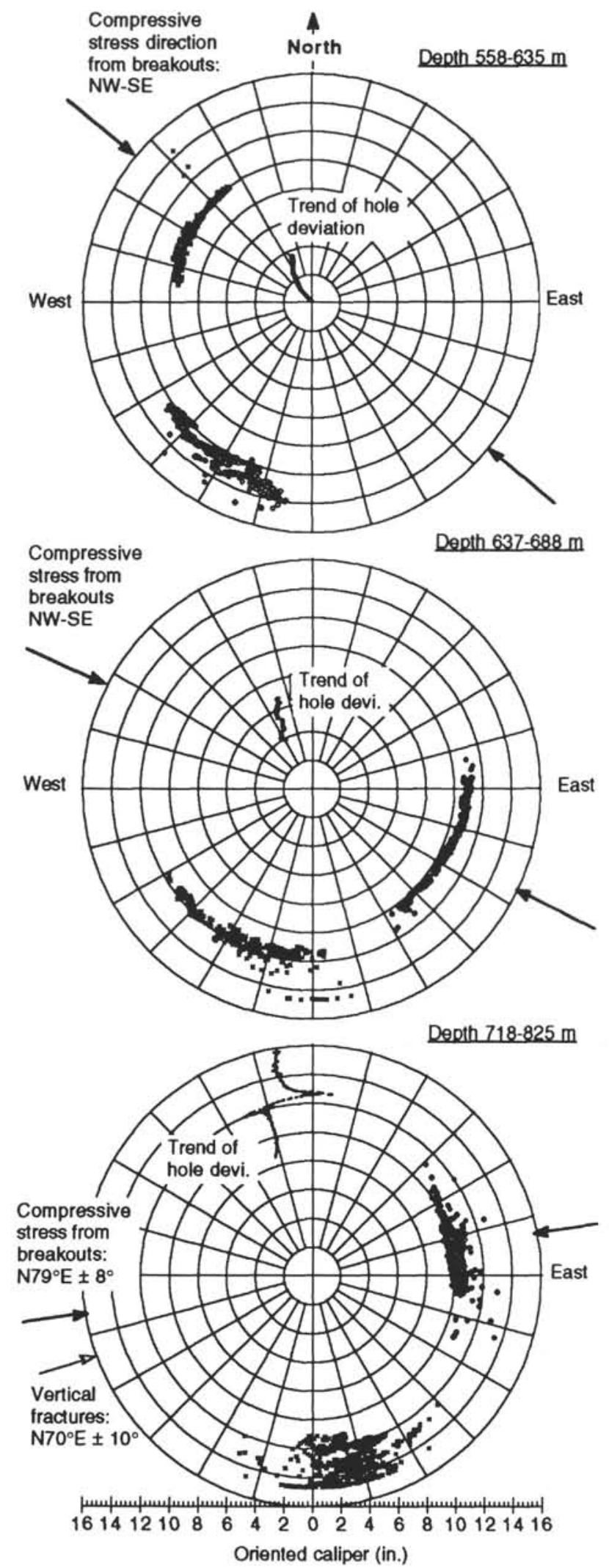

Figure 15. Orientation of borehole minimum and maximum diameter in three selected breakout intervals at Site 833. The horizontal projection of the trend of the borehole (plotted at a different scale) is indicated for comparison with the orientation of the elongation.

\section{REFERENCES ${ }^{\circ}$}

Antoine, J.N., and Delhomme, J.P., 1990. A method to derive dips from bed boundary in borehole images. Soc. Pet. Eng., 65th Ann. Technical Conf. and Exhibition, New Orleans, preprint, Pap. SPE-20540.

Borm, G., Lempp, C., Natau, O., and Röckel, T., 1989. Instabilities of borehole and drillcores in crystalline rocks, with examples from the KTB pilot hole. Sci. Drill., 1:105-114.

Bourke, L.T., 1989. Recognizing artifact images of the Formation MicroScanner tool. Trans. SPWLA 30th Ann. Logging Symp., Pap. WW.

Collot, J.-Y., Greene, H.G., Stokking, L.B., et al., 1992. Proc. ODP, Init. Repts., 134: College Station, TX (Ocean Drilling Program).

Daniel, J., Gérard, M., Mauffet, A., Boulanger, D., Cautin, B., Collot, J.-Y., Durand, J., Fisher, M., Greene, H.G., Michaux, P., Pelletier, B., Pezzimenti, A., Renard, V., Schaming, M., and Tissot, J.D., 1989. Déformation compressive d'un bassin intra-arc dans le contexte de collision ride/arc: le bassin d'Aoba, arc des Nouvelles-Hebrides. C. R. Acad. Sci. Ser. 2. 308:239-245.

Ekstrom, M.P., Dahan, C.A., Chen, M.-Y., Lloyd, P.M., and Rossi, D.J., 1986. Formation imaging with microelectrical scanning arrays. Trans. SPWLA 27th Ann. Logging Symp., Pap. BB. [Subsequently published in Log Analyst, 1987, 28:294-306.]

Gough, D.I., and Bell, J.S., 1982. Stress orientations from borehole fractures with examples from Colorado, east Texas, and northern Canada. Can. J. Earth Sci., 19:1358-1370.

Hansen, K.S., and Purcell, W.R., 1989. Earth stress measurements in the South Belridge oil field, Kern County, California. Soc. Pet. Eng., 61st Ann. Meeting, New Orleans, preprint, SPE-15641. [Subsequently published in SPE Form. Eval., 1989, 3:541-549.]

Louat, R., and Pelletier, B., 1989. Seismotectonics and present-day relative plate motions in the New Hebrides-North Fiji basin region. Tectonophysics, 167:41-55.

Mastin, L.G., Heinemann, B., Krammer, A., Fuchs, K., and Zoback, M.D., 1991. Stress orientation in the KTB pilot hole determined from wellbore breakouts. Sci. Drill., 2:1-12.

Pezard, P.A., and Luthi, S.M., 1988. Borehole electrical images in the basement of the Cajon Pass Scientific Drillhole, California; fracture identification and tectonic implications. Geophys. Res. Lett., 15:1017-1020.

Plumb, R.A., and Hickman, S.H., 1985. Stress-induced borehole elongation: a comparison between the four-arm dipmeter and the borehole televiewer in the Auburn geothermal well. J. Geophys. Res., 90:5513-5521.

Plumb, R.A., and Luthi, S.M., 1986. Application of borehole images to geologic modelling of an eolian reservoir. Soc. Pet. Eng., 61st Ann. Meeting, New Orleans, preprint, SPE-15487. [Subsequently published in SPE Form. Eval., 1989, 3:505-514.]

Rummel, F., 1988. Hydraulic fracturing stress measurements theory and practice. In Borm, G. (Ed.), Spaungsmessungen und Bohrlochstabilität, KTB-PL, NLFB, Hannover, KTB-Rep. 88-8:53-65.

Schlumberger, 1986. Dipmeter Interpretation Fundamentals: New York (Schlumberger), SMP-7002.

Serra, O., 1989. Formation MicroScanner Image Interpretation: Houston (Schlumberger Educ. Services), SMP-7028.

Taylor, E., and Leonard, J., 1990. Sediment consolidation and permeability at the Barbados forearc. In Moore, J.C., Mascle, A., et al., Proc. ODP, Sci. Results, 110: College Station, TX (Ocean Drilling Program), 289-308.

Zoback, M.D., Moos, D., Mastin, L., and Anderson, R.N., 1985. Well bore breakouts and in situ stress. J. Geophys. Res, 90:5523-5530.

, 1986. Discussion and reply to "Well bore breakouts and in situ stress," published in J. Geophys. Res., 90:5523-5530. J. Geophys. Res., 91:14161-14164.

Date of initial receipt: 5 May 1992

Date of acceptance: 8 March 1993

Ms 134SR-037

\footnotetext{
Abbreviations for names of organizations and publications in ODP reference lists follow the style given in Chemical Abstracts Service Source Index (published by American Chemical Society).
} 